\title{
THE ANALYSIS OF THE SERVICE QUALITY ON FRONT OFFICE DEPARTMENT IN BALI NUSA DUA HOTEL
}

\author{
Wayan Kiki Sanjaya ${ }^{1}$, A.A. Agung Wijaya ${ }^{2}$, Kadek Feni Aryati ${ }^{3}$, Reinaldo Rafael ${ }^{4}$ \\ International Bali Institute of Tourism \\ kikisanjayabali@gmail.com
}

\begin{abstract}
This study analyzes the guest satisfaction level of service quality on front office department in Bali Nusa Dua Hotel. As many hotels are emerging up, hence companies being required to improve the service quality on front office department in order to achieve customer satisfaction. In reality, although in generally, the services in Bali Nusa Dua Hotel is good, but having some shortcomings, this became an obstacle in improving the service quality. Therefore, the problem raised in this study is how the service quality and alternative strategies in improving the service quality on front office in Bali Nusa Dua Hotel. This is a quantitative descriptive research. The data of research were obtained from observations, questionnaires, interviews, and documentation studies. The data were further tabulated with the results of the study which found that although the average guest were satisfied with the front office service, empathy is needed to be optimized as one of the alternative strategies and as a screening study that led to the satisfaction of the guests staying overnight.
\end{abstract}

Keywords: Guest satisfaction; Service quality; Front office department.

\section{INTRODUCTION}

The background of this research is based on the demands of tourists who want to get adequate accommodation facilities in accordance with the price paid. The hotel as a means of accommodation should get organized continuesly in providing services for tourists. Theoretically, a hotel is a business entity that is engaged in commercially managed accommodation services provided for everyone who receives services and lodging (Sulastiyono, 2011: 15). If it is examined in deeper, service becomes the keyword about the above understanding of the hotel. Practically, if tourists are satisfied with the services provided by the hotel, then guests feel the amount of money paid in accordance with what is obtained. The opposite if not, then the phenomenon of guest not satisfied arises the guest unsatisfaction which end with guest complaint. In the world of hospitality, this phenomenon is common, but remains a serious concern, and is a struggle in many hotels in Bali, one of them appears in Bali Nusa Dua Hotel.

Preliminary research data found a gap between expectations and services provided at Bali Nusa Dua Hotel. This can be seen from the not satisfied customers in the front office services (front office), especially the reservation section at the Hotel. A bad review by a customer Tripadvisor (2017) on January 3, 2017, a 
Singaporean guest who is also a blogger (author of articles on internet media) expressed disappointment at the quality of service in the reservation section. The customer's not satisfied started with the incomplete room order that had been booked four months before the arrival date (check-in) was not in line with expectations. Not only that, other than the warm welcome that was not in accordance with the promotion on the Bali Nusa Dua Hotel website was not felt. In addition, guests also complained about the length of service to have to wait for 45 minutes.

Preliminary data findings that occurred at Bali Nusa Dua Hotel provide some critical understanding. First, practically, Bali-class-starred hotels in Bali Nusa Dua turned out to be an occasional quality of service that has not been able to accommodate holistic tourist satisfaction. If viewed theoretically, service quality is one of the determining factors for customer satisfaction. This argument is supported by the idea of Lewis and Booms in Tjiptono, (2005: 121) that service quality is a measurement of how good the level of service provided is in accordance with customer expectations. That is, a five-star hotel like Bali Nusa Dua Hotel is also required to provide more services and even exceed the expectations and value of money paid. Second, tourist complaints to be written on the online reservation media certainly have an impact on imaging services that have been built and promoted by the Bali Nusa Dua Hotel. Third, there has never been a similar study related to service satisfaction at the front office department at the hotel which makes an urgency because if this is not solved then the imaging and hotel services in the future are assumed to have decreased. The problem raised is how the quality of service at the front office department in Bali Nusa.

\section{LITERATURE REVIEW}

In this study, the concepts used are hospitality and front office while the theory is service quality and service quality dimensions. The first concept, namely hospitality, according to the Decree of the Minister of Tourism, Post and Telecommunications No.KM 37 / PW-340 / MPT-86, is a type of accommodation that uses part or all of the building to provide lodging, dining and drinking services, and other services to the public which is managed commercially (Somad \& Priansa, 2014: 2)Based on that definition it is concluded that the hotel is a business that is a supporting facility related to service in order to meet or satisfy the wishes of the community.

The second concept discussed is front office. Front office when referring to the designation in the hotel world is often termed the front office department. The department is the most important position for the continuity of the hotel because the front office is dealing directly with guests. The good and bad of a hotel depends on the services provided by each hotel, (Soenarno, 2000: 2).

From a theoretical point of view in this study, the theory of service quality as the first theory discussed according to Kotler (2000: 25); Nasution (2004: 47) gives the idea that service quality is the totality of the form of characteristics of goods and services whose ability to satisfy customer needs. Furthermore, service quality is not seen from the point of view of the provider or service provider but based on customer perception. In other words, customers who consume and feel service can judge and determine service quality. 
Furthermore, Parasuraman in Nasution (2004: 60) explains that there are two factors that affect the quality of service. First, perceived service that has the meaning of services received and felt by customers in accordance with expectations, the perceived quality of service is good and satisfying. Second, expected service which has the understanding that the service received exceeds customer expectations, the service quality is perceived as ideal quality. The theory of service quality was chosen and used in this study as a parameter of achieving service quality in Bali Nusa Dua hotels as well as looking at the extent of services provided by the front office of the hotel.

The second theory, the dimensions of service quality used in this study, refers to the idea of Parasuraman with the following explanation. The essence of the concept of service quality is to show all forms of actualization of service activities that satisfy customers who receive services rendered consistently to satisfy them through five dimensions of service, namely: in accordance with responsiveness, fostering the existence of assurance, showing the tangible that can be seen, according to of people who provide empathy and in accordance with their reliability carrying out the service duties (Parasuraman, 2001: 26). The five service dimensions are explained by Parasuraman as follows.

\section{a. Responsiveness}

Each employee in providing forms of service prioritizes aspects of detail. That is, services require a wise explanation, detailed, fostering, directing and persuading so that the form of service seems to have a positive response (Parasuraman, 2001: 52).

\section{b. Assurance}

Every form of service requires certainty of the services provided. The form of certainty of a service is largely determined by the guarantee of employees who provide services, therefore guests who receive services are more satisfied and confident that all forms of service affairs provided will be completed and completed in accordance with the speed, accuracy, convenience, smoothness, and quality of services provided (Parasuraman, 2001: 69).

\section{c. Tangible}

Understanding the tangible in service quality is a form of actual physical actualization that can be seen or used by employees according to their use and utilization which can be felt to help the services received by people who want service, therefore that they are satisfied with the service felt, which also shows work performance for giving services provided (Parasuraman, 2001: 32).

\section{d. Empathy}

Every service activity or service requires an understanding and understanding of the togetherness of assumptions or interests in a matter related to service. Services will run smoothly and quality if every party concerned with the service has a sense of empathy in completing or managing or having the same commitment to service (Parasuraman, 2001: 40).

\section{e. Reliability}

Each service requires a reliable form of service, meaning that in providing services, every employee is expected to have the ability in knowledge, expertise, independence, mastery, and high professionalism of work, so that the work activities carried out produce satisfactory forms of service, without any complaints 
and impressions, excessive service received by the community (Parasuraman, 2001: 48).

\section{METHODOLOGY}

This research is a quantitative descriptive study. In an effort to obtain valid and reliable answers related to the formulation of the problem, At least 120 questionnaires have been created, distributed, and distributed randomly by random sampling method to 120 respondents who stayed at Bali Nusa Dua hotel. In addition, observations were also carried out over a two-month period from September to November 2018 to strengthen data and findings related to service quality in the front office department.

Furthermore, the collected data were analyzed using ServQual analysis to find the phenomenon of service that occurred in Bali Nusa Dua hotel. The research tools are theoretical from Parasuraman about the five dimensions of service that are used as a benchmark in making questionnaires and see the extent of the implications of the theory in the hotel world so that alternative strategies of phenomena that can occur in the hotel can be found.

\section{RESULTS}

\section{RESULTS AND DISCUSSIONS}

From the research data which at the same time answered the research problem statement, it was found several facts that occurred in Bali Nusa Dua hotel. At least 120 questionnaires have been made and distributed randomly to get valid and reliable answers in accordance with the desired context as many as 90 respondents who stayed at Bali Nusa Dua hotel. Data recapitulation can be seen in table 4.1 Table 4.1 Recapitulation of respondents' ratings on the level of guest satisfaction with the quality of front office services at Bali Nusa Dua Hotel

\begin{tabular}{|l|c|c|}
\hline \multicolumn{1}{|c|}{ Dimension } & $\begin{array}{c}\text { ServQual } \\
\text { Score }\end{array}$ & Information \\
\hline Tangible & 0,19 & Very Satisfied \\
\hline Reliability & $-0,02$ & Not Satisfied \\
\hline Responsiveness & $-0,10$ & Not Satisfied \\
\hline Assurance & 0,17 & Very Satisfied \\
\hline Empathy Average & $-0,08$ & Not Satisfied \\
\hline \multicolumn{1}{|c|}{ A } & $\mathbf{0 , 0 3}$ & Very Satisfied \\
\hline
\end{tabular}

Source: primary data processed in 2018

Based on the results of the satisfaction level analysis with front office services at Bali Nusa Dua Hotel, an average value of 0.03 was obtained. If referring to the satisfaction value according to Tjiptono (2012: 182), then the value of 0.03 is included in the category of expectations more than fulfilled or very satisfied.

Interested in dissecting a number of service dimensions that were not in line with expectations, the data were analyzed further. Using ServQual analysis, it was found that there are four service phenomena that occur in Bali Nusa Dua hotels.

First, the perception and expectations of the empathy dimension are still unsatisfactory. This can be seen in table 4.1. which shows that overall respondents 
were not satisfied with all the indicators contained in the empathy dimension, this is indicated by the average ServQual value of -0.08 .

Secondly, the assessment of the employee's ability to communicate indicators was also highlighted by respondents with unsatisfactory scores with the not satisfied category with an average ServQual score of -0.39 .

Third, an assessment of the desire indicators in listening to the wishes of guests, it appears that the category of not satisfied was also a finding in Nusa Dua hotels with a ServQual score of -0.21 .

Fourth, the assessment of serving without distinguishing guests and giving personal attention is included in the very satisfying category with a ServQual score of 0.07 on points and satisfaction is also apparent from the assessment of frontoffice employees who provide services to meet guest needs with a ServQual score of 0.10 .

The fifth is the assessment of front-office employees in the form of giving personal attention to getting a very satisfying score with a ServQual score of 0.01 . The full score about perceptions, expectations, ServQual scores, and respondents' satisfaction with each criterion can be seen from table 4.2.

Table 4.2 Perceptions and Expectations of Empathy dimension in Bali Nusa Dua Hotel

\begin{tabular}{|c|c|c|c|c|}
\hline Empathy & $\begin{array}{c}\text { Guests' } \\
\text { Perceptio } \\
\text { ns }\end{array}$ & $\begin{array}{c}\text { Guests' } \\
\text { Expectatio } \\
\text { ns }\end{array}$ & $\begin{array}{l}\text { ServQua } \\
\text { l Score }\end{array}$ & Information \\
\hline $\begin{array}{l}\text { 1. The ability of employees } \\
\text { to communicate }\end{array}$ & 3.96 & 3.57 & -0.39 & Not Satisfied \\
\hline $\begin{array}{l}\text { 2. The desire to listen to the } \\
\text { wishes of guests }\end{array}$ & 4.17 & 3.96 & -0.21 & Not Satisfied \\
\hline $\begin{array}{ll}\text { 3. Serve } & \text { without } \\
\text { distinguishing guests }\end{array}$ & 3.92 & 3.99 & 0.07 & $\begin{array}{c}\text { Very } \\
\text { Satisfied }\end{array}$ \\
\hline $\begin{array}{l}\text { 4. Front office employees } \\
\text { understand the needs of } \\
\text { guests }\end{array}$ & 4.23 & 4.33 & 0.10 & $\begin{array}{c}\text { Very } \\
\text { Satisfied }\end{array}$ \\
\hline $\begin{array}{l}\text { 5. Front office employees } \\
\text { give personal attention }\end{array}$ & 4.22 & 4.23 & 0.01 & $\begin{array}{c}\text { Very } \\
\text { Satisfied }\end{array}$ \\
\hline Average & 4.10 & 4.02 & -0.08 & $\begin{array}{c}\text { Not } \\
\text { Satisfied } \\
\end{array}$ \\
\hline
\end{tabular}

To clarify how the service quality of the front office department in Bali Nusa Dua Hotel, the data can be seen from the Cartesian diagram compiled in Figure 4.1. 
Figure 4.1 Kartesius's diagram of the level of guest satisfaction with the quality of front office services at Bali Nusa Dua Hotel

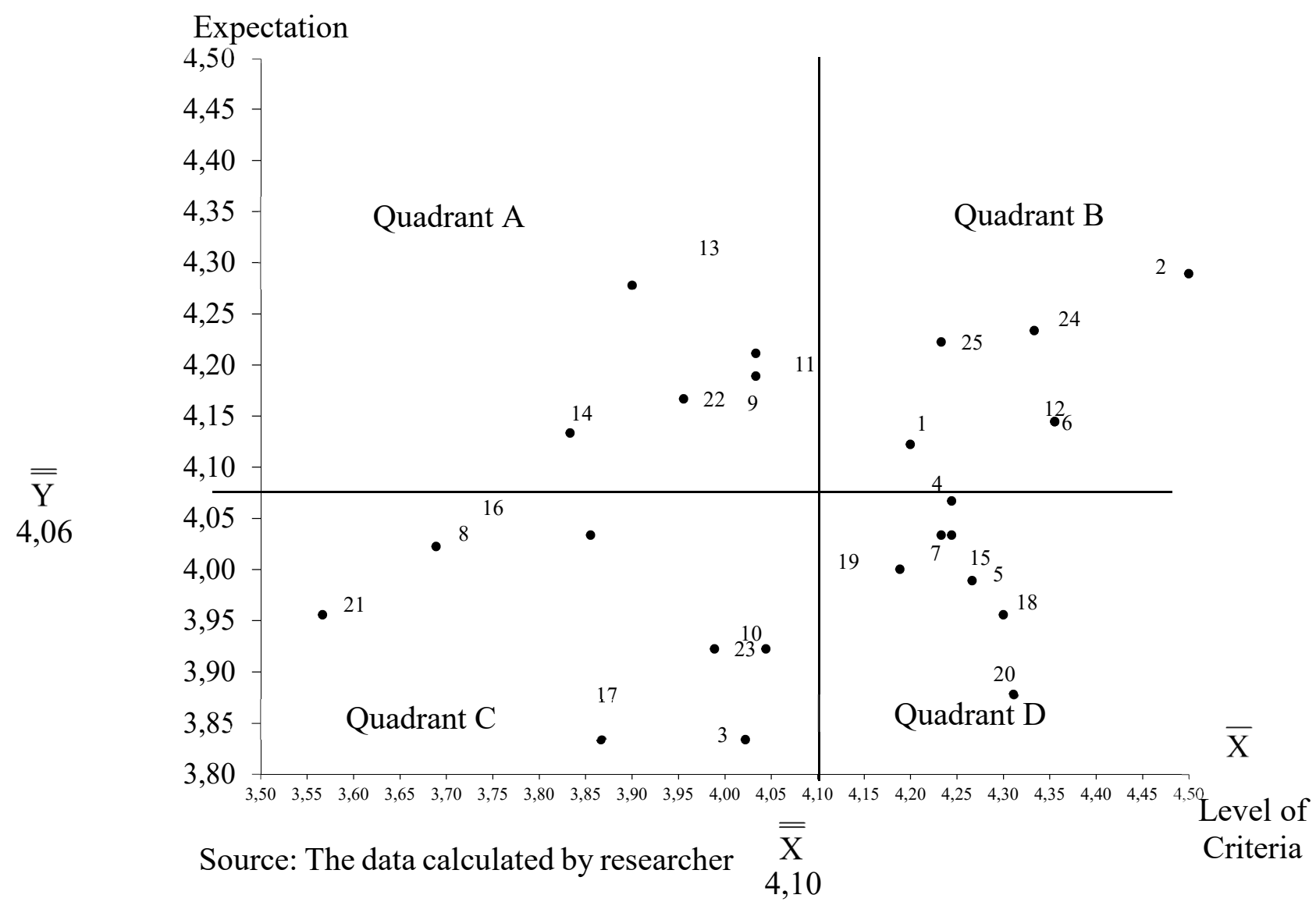

Information:

Quadrant A: Top Priority

Quadrant B: Maintain Performance

Quadrant C: Low Priority

Quadrant D: Exaggerated Priorities

From the Cartesian diagram above it can be seen that the indicators that influence guest satisfaction at Bali Nusa Dua Hotel are divided into four quadrants. Based on the theory by Supranto regarding the Cartesian diagram previously explained in Chapter III, the interpretation of the Cartesian diagram can be explained as follows:

1. Quadrant A

Factors that occupy this quadrant indicate that these factors are considered to affect guest satisfaction, but management has not implemented it according to guest wishes. The five factors in this quadrant are:

a. Factor no. 9: Front office staff serves appropriately

b. Factor 11: Front office employees provide the desired information

c. Factor no. 13: Front office staff can handle guest complaints

d. Factor no. 14: Front office employees provide fast service 
e. Factor no. 22: The desire to listen to the wishes of guests

2. Quadrant B

Factors or indicators that exist in quadrant $B$ are elements of the basic services that have been successfully carried out by the hotel for this to be maintained. The indicators included in quadrant B are as follows.

a. Factor no. 1: Employee appearance

b. Factor no. 2: Situations and conditions in the front office area

c. Factor no. 12: Front office employees provide meticulous service

d. Factor no. 24: Front office staff understands guests' needs

e. Factor no. 25: Front office staff gives personal attention

f. Factor no. 6: timeliness in handling the check-in / check-out process.

3. Quadrant C

Factors that are in quadrant $\mathrm{C}$ are the factors that are less important influence according to guests and the implementation is ordinary by the hotel. The indicators included in quadrant $\mathrm{C}$ are as follows.

a. Factor no. 3: Quality of front office equipment

b. Factor no. 8: Front office employees provide services as promised

c. Factor no. 10: Sensitivity in providing guest needs

d. Factor no. 16: Front office staff provides clear information

e. Factor no. 17: Front office employee polite behavior

f. Factor no. 21: The ability of employees to communicate

g. Factor no. 23: Serve without distinguishing guests

4. Quadrant D

Factors or indicators contained in quadrant $\mathrm{D}$ are indicators that do not affect guest satisfaction, but the implementation is excessive by the hotel. The indicators included in quadrant $\mathrm{D}$ are as follows.

a. Factor no. 4: Cleanliness of the front office area and equipment

b. Factor no. 5: Facilities in the front office area

c. Factor no. 7: Accuracy in serving guests

d. Factor no. 18: Friendliness of front-office employees

e. Factor no. 19: Attitude of attention of front-office employees

f. Factor no. 20: The ability of the front office to maintain guest comfort

g. Factor 15: Feel safe when served by front office employees

\section{DISCUSSION}

\section{Discussion of Front Office Services Quality in Bali Nusa Dua Hotels}

In an effort to realize good service quality and in meeting customer expectations, Bali Nusa Dua Hotel must at least adopt a theoretical dimension of service. Although theoretically, the front office department employees at the hotel did not really understand the theoretical five dimensions of service, they had practiced autodidactically in accordance with the service dimension theory. In the tangible dimension, for example, the quality of front office services in Bali Nusa Dua Hotel shows that the ServQual analysis results are very satisfying. The implications of the Parasuraman theory are evident when front-office employees at Nusa Dua Bali hotels strive to create guest satisfaction in the dimension of physical evidence. This can be proven when the front office department employees maintain the ideal conditions of the SOP in an effort to improve service quality. As a result, guests are always and remain satisfied with the appearance of employees, the 
situation and condition of the front office area, the quality of equipment, the cleanliness of the area and the existing facilities. The condition that seems to be in line with the service theory from Parasuraman is a strategy in increasing the satisfaction of consumers of Bali Nusa Dua Hotel.

In the results of data analysis about the assurance dimension, the same thing is repeated. What is meant by the same thing that is repeated is that the hotel seems to have a strategy of prioritizing service quality as a guarantee of satisfaction? As a result, the very satisfied category was successfully obtained and carried by the front office department in Bali Nusa Dua Hotel from the questionnaire results. This seems to be in the same direction and is a strategy that has been used by the hotel from year to year. The fact that front office employees optimally provide services in the delivery of information about products and the clarity of existing facilities in the hotel becomes a separate strategy that is automatically manifested by Parasuraman's theory about the service dimension. In other words, critically examined from the Bali Nusa Dua hotel strategy is the quality of equipment, cleanliness, and information services at the hotel is a strategy to maintain customer satisfaction.

The above other dimensions seem to contradict that it is not as expected. On the quality dimension of reliability, the dimension of responsiveness, and the dimension of responsiveness are services that are underlined needing review. In an effort to explore further related to the causes of the three dimensions, the phenomenon was not yet found to be maximum when it was observed that the group guest factor caused the outbreak of concentration from front office staff and reduced service quality. For example, in October 2018 during observation, a group of about twenty people from China appeared to gather in the lobby of the Nusa Dua Bali Hotel to check-in (registration). The observation also found that some guests were not fluent in English so the lines at the front office counters were endless. This was made worse by the condition of the front office with only two staff plus one trainee and a front office manager. If related to the results of the questionnaire collected, nearly 50 percent of the questionnaires were Chinese guests from China. Relevance, the service is not fast, lack of clarity of information due to language problems, and the lack of empathy from the front office staff becomes the assessment of the guests filling the questionnaire.

If it is related to the theoretical proposed by Parasuraman (2001: 48), the phenomenon that occurs in the front office of Bali Nusa Dua hotel is not in accordance with the theoretically ideal conditions of Parasuraman. In an effort to optimize the quality of front office services, on the reliability dimension that is closely related to the ability of front-office employees, it is expected that front office staff should try their best to provide services according to the promise needed by each guest, therefore what is expected by guests can in accordance with what was promised.

In the dimension of responsiveness based on the results of the analysis of the dimensions of responsiveness obtained from respondents' assessments, it is known that a factor influencing guest not satisfied is the lack of front-office employees providing the information desired by guests, employees have not been able to handle guest complaints and front employees office has not provided fast service. Whereas in theory, Parasuraman (2001: 52) explains that "service demands are if those who provide services find the person being served not understanding either 
procedure or mechanism, then it is necessary to give a clear and wise understanding and understanding and provide various alternatives ease to follow the right service requirements, therefore the impression of people who get service understands or responds to the desires of the people being served. "

If it is linked between the practice that occurs with the Parasuraman theory, then it is not in accordance with the expectations contained in the theory. Therefore, efforts can be made to optimize the quality of front office services, especially in this responsiveness dimension, namely the need for good communication between front-office employees and guests therefore, all information conveyed to guests can be as expected by guests.

In addition, good handling of complaints can provide opportunities to turn a not satisfied guest into a satisfied guest for the services provided. An effective complaint handling process should start by identifying the source of the problem that causes guests to feel not satisfied or complaining. The source of this problem needs to be addressed, acted upon and endeavored to avoid the same problem in the future.

On the service dimension of empathy, based on the data obtained from the questionnaire, guests at Bali Nusa Dua Hotel were not satisfied with the ability of the front office staff to communicate as well as the lack of employee willingness to listen to guests' wishes. Efforts can be made to maintain and improve the quality of front office services in this empathy dimension, namely by increasing awareness of complaints and needs of guests during a stay at Bali Nusa Dua Hotel in accordance with expectations in the theory of Parasuraman (2001: 40), namely the service will run with smooth and quality if every party concerned with service has a sense of empathy in completing or managing or having the same commitment to service, but in reality, what happens at the Bali Nusa Dua hotel is not the case.

\section{Conclusions}

\section{CONCLUSIONS AND SUGGESTIONS}

From the results of the discussion of this study, it was concluded two things related to the service of front office department in Bali Nusa Dua hotel. First, the service at the Bali Nusa Dua hotel is satisfactory, but there are several dimensions of service that still need to be improved. The service dimension is reliability, responsiveness, and sensitivity in terms of hotel service empathy. Second, the lack of a maximum of three dimensions of service is caused by factors, for example, the lack of hotel staff serving group guests, the lack of language acquisition for those who have specifications rather than native English speakers such as tourists from China.

\section{Suggestion}

Based on the research conclusions about the service of front office department in Bali Nusa Dua Hotel, two suggestions can be given. The first suggestion, practically there needs to be coordination between the front office team at the hotel so that it does not occur until the phenomenon is less satisfying when handling group guests. The second suggestion, specific to the three service dimensions that still need to be improved are training efforts and improving service quality as well 
as making SOP on the service of guest group. The aim is to be able to minimize the occurrence of guest complaints as the research findings above.

\section{REFERENCES}

Kotler, P. (2000). Prinsip-Prinsip Pemasaran Manajemen. Prenhalindo.

Nasution, M. N. (2004). Manajemen jasa terpadu. Ghalia Indonesia.

Parasuraman, A. V. (2001). Perception of Service Quality. (Purwoko (Trans.)). Allyn and Bacon.

Decree of the Minister of Tourism, Post and Telecommunications No.KM 37 / PW340 / MPT-86, (1987).

Soenarno, A. (2000). Front Office Management. Andi.

Somad, R., \& Priansa, D. J. (2014). Manajemen Komunikasi Mengembangkan Bisnis Berorientasi Pelanggan. Alfabeta.

Sulastiyono, A. (2011). Seri Manajemen Usaha Jasa Sarana Pariwisata dan Akomodasi: Manajemen Penyelenggaraan Hotel. Alfabeta.

Tjiptono, F. (2005). Pemasaran Jasa (1st ed.). Penerbit Bayumedia Publishing. Tjiptono, F. (2012). Service management mewujudkan layanan prima. Andi.

Tripadvisor. (2017). Bali Nusa Dua Hotel. https://www.tripadvisor.co.id/Hotel_Review-g297698-d6640840-ReviewsBali_Nusa_Dua_Hotel-Nusa_Dua_Nusa_Dua_Peninsula_Bali.html 